ADVANcES IN

PSYCHIATRY \& NEUROLOGY

POSTEPY

Psychiatrii i Neurologii

\section{Impact of obstructive sleep apnea syndrome on peripheral nerves and the effect of continuous positive airway pressure: a prospective observational case series}

\author{
Wpływ obturacyjnego bezdechu \\ sennego na nerwy obwodowe \\ oraz efekt leczenia ciągłym dodatnim \\ ciśnieniem w drogach oddechowych: \\ prospektywna obserwacyjna seria \\ przypadków
}

Correspondence to/Adres do korespondencji:

Jakub M. Antczak

Department of Clinical Neurophysiology

Institute of Psychiatry and Neurology

9 Sobieskiego St.

02-957 Warsaw, Poland

e-mail: jacob.antczak@gmail.com

Submitted/Otrzymano: 28.06.2021

Accepted/Przyjęto do druku: 31.08.2021

\author{
Jakub M. Antczak ${ }^{1,2}$ D , Aleksander Kania' ${ }^{D}$, \\ Maria Dąbroś' , Kinga Budnicki' , Ravin De Fonseka', \\ Marta Banach' (D), Agnieszka Słowik' (D)
}

'Department of Neurology, Jagiellonian University Medical College, Krakow, Poland
'Department of Clinical Neurophysiology, Institute of Psychiatry and Neurology, Warsaw, Poland

\begin{abstract}
Purpose: Obstructive sleep apnea syndrome (OSAS) is suggested to have a strong association with peripheral neuropathy (PNP). However, knowledge about this relationship is still very limited. The aim of this prospective case series was to investigate the peripheral nerves in OSAS patients, along with related clinical symptoms, and to assess the effect of continuous positive airway pressure (CPAP) therapy.

Methods: The nerves of upper and lower extremities of 25 patients with moderate to severe OSAS who complained of symptoms suggestive of peripheral neuropathy (PNP) were investigated electrophysiologically. The cross-sectional area (CSA) of the median nerve at the wrist and of the ulnar nerve in the epicondylar groove were assessed with ultrasound. Fifteen patients who showed abnormalities were then reassessed after 3 months of CPAP therapy, and again after an additional 6 months.

Results: The most common findings were carpal tunnel syndrome (CTS) and ulnar neuropathy at the elbow (UNE). Surprisingly, CTS was seen in ultrasound twice as frequently as in electrophysiology. The main symptom was numbness in the upper and lower extremities. CPAP therapy reduced the CSA, improved the conduction at entrapment sites and alleviated the symptoms in some of the patients.

Conclusions: CTS and UNE are the most frequent neuropathies in patients with OSAS. However, the clinical symptoms tend to be more generalized. CPAP therapy seems to be beneficial for both objective measurements and subjective symptoms.

Key words: obstructive sleep apnea syndrome, continuous positive airway pressure, carpal tunnel syndrome, ulnar neuropathy, numbness, neural edema, peripheral neuropathy.
\end{abstract}

\title{
Streszczenie
}

Cel: Obturacyjny bezdech senny (OBS) jest prawdopodobnie związany z występowaniem neuropatii obwodowej (NO), jednak wiedza na temat związku OBS z NO jest ograniczona. Celem obecnego badania była ocena nerwów obwodowych w OBS, ocena subiektywnych dolegliwości związanych z NO oraz ocena wpływu leczenia ciągłym dodatnim ciśnieniem w drogach oddechowych (CDCDO).

Metody: Wykonano badanie przewodnictwa nerwowego nerwów kończyn górnych i dolnych u 25 pacjentów ze średnio nasiloną bądź ciężką postacią OBS, skarżących się na dolegliwości typowe dla NO. W zakresie nerwów pośrodkowego i łokciowego wykonano także badanie ultrasonograficzne $\mathrm{z}$ oceną pola powierzchni przekroju poprzecznego (PPPP), odpowiednio w nadgarstku 
Impact of obstructive sleep apnea syndrome on peripheral nerves and the effect of continuous positive airway pressure: a prospective observational case series

Wpływ obturacyjnego bezdechu sennego na nerwy obwodowe oraz efekt leczenia ciagłym dodatnim ciśnieniem w drogach oddechowych: prospektywna obserwacyjna seria przypadków

i w rowku nerwu łokciowego. U 15 chorych, którzy wykazali nieprawidłowości, badania powtórzono po 3 i po 9 miesiącach od wprowadzenia terapii CDCDO.

Wyniki: Najczęstszą postacią neuropatii obwodowej był zespół cieśni nadgarstka (ZCN) i neuropatia nerwu łokciowego w rowku. Obie te neuropatie występowały niemal dwukrotnie częściej w ultrasonografii niż w badaniu przewodnictwa. Chorzy skarżyli się najczęściej na drętwienie kończyn górnych i dolnych. Terapia CDCDO spowodowała zmniejszenie PPPP oraz poprawę parametrów przewodzenia w miejscach cieśni. Część chorych zauważyła także zmniejszenie nasilenia dolegliwości.

Wnioski: Najczęstszą postacią neuropatii obwodowej w OBS są ZCN i neuropatia nerwu łokciowego w rowku, jednakże subiektywne objawy mają bardziej uogólniony charakter. Terapia CDCDO wydaje się korzystnie wpływać zarówno na obiektywne pomiary, jak i subiektywne dolegliwości związane z neuropatią obwodową.

Słowa kluczowe: obturacyjny bezdech senny, ciągłe dodatnie ciśnienie w drogach oddechowych, zespół cieśni nadgarstka, neuropatia nerwu łokciowego, drętwienie, obrzęk nerwu, neuropatia obwodowa.

\section{INTRODUCTION}

Obstructive sleep apnea syndrome (OSAS) is associated with abnormal results of nerve conduction studies (NCS) indicative of peripheral neuropathy (PNP) [1-3], including the most common compression neuropathies, such as carpal tunnel syndrome (CTS) and ulnar neuropathy at the elbow (UNE) $[4,5]$. However, current knowledge about the relationship between OSAS and PNP still has significant limitations: the first is the paucity of knowledge about subjective peripheral neuropathy complaints, which have been assessed only with respect to CTS and UNE $[4,5]$. The second is the scarcity of data on the effect of treatment with positive continuous airway pressure (CPAP). Changes occurring under this therapy have been investigated only with respect to the amplitude of the sensory nerve action potential (SNAP) of the sural nerve [2], and to the sensory conduction and functional resistance to ischemia of the median nerve [1].

In this prospective, exploratory case series, we wanted to obtain a view of the general characteristics of the involvement of peripheral nerves in OSAS patients by investigating nerves of the upper and lower extremities, along with the subjective symptoms of PNP. The second purpose was to expand our knowledge about the impact of CPAP therapy on peripheral nerves.

\section{METHODS}

The Ethics Committee of the Jagiellonian University approved the protocol (Permission No. 1072.6120.18.2017). All participants gave their written, informed consent. The study was conducted in accordance with the Declaration of Helsinki.

\section{Participants}

We included patients with apnea hypopnea index $(\mathrm{AHI}) \geq 15$ with mainly obstructive events. Further inclusion criteria were treatment with CPAP, which followed a diagnosis of OSAS and subjective symptoms of PNP, such as numbness, burning pain, loss of temperature sensation and others as listed in Part A of the Michigan Neuropathy Screening Instrument (MNSI) [6], and scoring up to four or more points therein. The exclusion criteria were age $<18$ years, diabetes, B12 deficiency, other severe deficiencies, significant hypothyroidism and a history of inflammatory, genetic or other PNP, as well as an active neoplastic process. Patients were recruited in the ambulatory setting of the Department of Pulmonology at the University Hospital in Cracow, Poland.

\section{Diagnostics and treatment of obstructive sleep apnea syndrome}

Subjects underwent attended diagnostic nocturnal polysomnography in the Sleep Laboratory of the Department of Pulmonology of the University Hospital in Cracow. They slept in a comfortable bed, in a sound- and light-attenuated room. The recorded signals included: electroencephalography derived from F3, F4, C3, C4, O1 and $\mathrm{O} 2$ electrodes, electrooculogram, electrocardiogram, mentalis and tibialis anterior electromyography recorded with surface electrodes, airflow measured by thermistor and nasal pressure transducer, and snoring recorded with the microphone attached to the skin of the neck. Respiratory movements were monitored with inductance bands placed around thorax and abdomen and blood oxygen saturation was monitored with finger oximetry. Throughout the night, subjects were videotaped with an infrared camera. Recordings were made with the Alice 6 Diagnostic Sleep System (Philips North America Corporation, 3000 Minuteman Road, M/S 109, Andover, MA 01810, USA). Respiratory events were scored according to the guidelines of the American Academy of Sleep Medicine [7]. The diagnostic polysomnography was followed on the next night by another session of polysomnography, during which the adjustment of effective treatment with CPAP was made. After a further three months, patients returned to the sleep laboratory, where their therapy compliance and respiratory parameters were read out from the CPAP device. 


\section{Diagnostics of neuropathy}

The neurological examination included bilateral checking of the muscle tonus in the main joints as well as the strength of distal parts of lower and upper extremities according to the Medical Research Council Grading System [8], and an examination of tendon reflexes. Moreover, vibration was investigated with the graduated RydelSeiffer tuning fork bilaterally on the medial malleoli and radial styloids [9]. Motor nerve conduction (MNC) was studied in the median, ulnar, peroneal and tibial nerves, and sensory nerve conduction (SNC) in the median, ulnar and sural nerve of the nondominant side of the body. Patients in whom the history or the neurologic investigation retrieved symptoms and/or signs suggestive of one or more focal neuropathies on the dominant side, irrespective of nerve or nerves, were additionally electrophysiologically tested. Motor and sensory electrophysiologic responses were recorded with superficial electrodes placed in accordance with widely accepted techniques. Similarly, the sites of the stimulation of the investigated nerves were adopted from commonly used suggestions [10]. For SNC the antidromic technique was used. The temperature on the skin surface, in the area where neurophysiologic responses were recorded, was maintained between 32 and 34 Celsius. Nerve conduction was assessed using normal values of our laboratory. Measurements were done with the Viking Quest electromyograph (Natus Neurology, 3150 Pleasant View Road, Middleton, WI 53562 USA). Ultrasonographic measurement of the cross-sectional area (CSA) of the median nerve at the level of the distal wrist crease and of the ulnar nerve in the epicondylar groove was done in patients who showed any abnormality in NCS or had symptoms suggesting entrapment neuropathy. Similarly to the electrophysiologic diagnostics, the nerves on the nondominant side were scanned and, in addition, the nerves on the dominant side when the clinical suspicion of respective median or ulnar neuropathy emerged. Normative data for median and ulnar CSA were adopted from Zaidman et al. [11], where the abnormal CSA for median nerve at the wrist is considered $\geq 12 \mathrm{~mm}^{2}$ and for the ulnar nerve in the cubital tunnel $\geq 11 \mathrm{~mm}^{2}$. The nerve ultrasound was made with a $14 \mathrm{MHz}$ linear probe and with the VIVID Pro7 device General Electric Healthcare (Chicago, Illinois, United States). All measurements were done thrice: at the first visit, before the patient began CPAP therapy, then at the second visit, which took place three months after CPAP-therapy had been started, and at the third visit, six months after the second one (nine months after CPAP started). Electrophysiologic and ultrasonographic measurements were performed at the Laboratory of Clinical Neurophysiology of the Department of Neurology of the Jagiellonian University in Cracow.

\section{Statistical analysis}

The relation of parameters of OSAS severity with particular NCS parameters and nerve CSA of nondominant extremities was assessed by calculating the Spearman correlation coefficient. NCS parameters and CSA were compared between the subsequent visits separately for compliant and for noncompliant patients, i.e. those who used CPAP $\geq 4$ or $<4$ hours per night on average. Comparative statistics were applied whenever the sample had a sufficient size. Otherwise, data are presented descriptively as mean and standard deviation. Calculations were performed using the Statistica data analysis software system, version 13.0 (StatSoft, 2008; Palo Alto, CA, USA). The significance level was set at $p<0.05$.

\section{RESULTS}

We recruited 25 patients. Nine of them showed no electrophysiological signs of PNP. There was also one that did not start CPAP. The second and third visits were carried out with the remaining 15 patients, of whom 5 were noncompliant.

The mean AHI of patients who showed no objective signs of PNP was $47.6 \pm 15.4$, the mean oxygen desaturation index (ODI) was $40.1 \pm 28.1$, and the mean arterial oxygen saturation was $94.1 \pm 3.1 \%$. Respective values for the group with objective signs of PNP were $47.2 \pm 21.6$, $46.0 \pm 28.1$ and $93.9 \pm 1.4 \%$. The demographic data of compliant and noncompliant patients is presented in Table 1.

\section{Relation of obstructive sleep apnea syndrome severity with neuropathy}

Significant correlations were found between AHI and amplitude of sural SNAP $(R=-0.415, p=0.049)$, ODI and amplitude of sural SNAP $(R=-0.450, p=0.031)$, as well as between mean $\mathrm{SaO}_{2}$ and motor conduction velocity across the elbow in the ulnar nerve $(R=0.418$, $p=0.047)$. Other parameters tested, i.e. distal motor latency of the median nerve, sensory conduction velocity of the median nerve, amplitude of ulnar SNAP, as well as median and ulnar CSA, showed no correlation with AHI, ODI and mean $\mathrm{SaO}_{2}$.

Table 1. Demographic and OSAS characteristics of compliant and noncompliant patients

\begin{tabular}{l|c|c|}
\hline Factor & Compliant patients & Noncompliant patients \\
\hline Sex & $1 \mathrm{~F} \mathrm{9M}$ & $1 \mathrm{~F} \mathrm{4M}$ \\
\hline Age & $52.4 \pm 11.8$ & $4 ., 6 \pm 6.8$ \\
\hline BMI & $32.6 \pm 3.7$ & $31.0 \pm 6.9$ \\
\hline AHI & $49.5 \pm 21.8$ & $37.9 \pm 20.4$ \\
\hline AHI with CPAP & $3.2 \pm 2.4$ & $4.0 \pm 2.6$ \\
\hline
\end{tabular}


Impact of obstructive sleep apnea syndrome on peripheral nerves and the effect of continuous positive airway pressure: a prospective observational case series

Wpływ obturacyjnego bezdechu sennego na nerwy obwodowe oraz efekt leczenia ciagłym dodatnim ciśnieniem w drogach oddechowych: prospektywna obserwacyjna seria przypadków

\section{Subjective symptoms of neuropathy}

Symptoms of neuropathy included mainly the numbness of lower and upper extremities. One patient complained about leg cramps and another about an urge to move his lower extremities in the evening. Five patients reported that the symptoms were exacerbated during night, and in one exacerbation occurred in the morning. In four patients the symptoms were more exacerbated in one upper extremity than in other extremities. After 3 months CPAP, 6 out of the 10 compliant patients reported an improvement of the subjective symptoms of neuropathy. The other three patients saw no changes, and in one the symptoms worsened. From the second to third visit there was further improvement in five patients. Four remained unchanged. One patient did not attend the third visit.

Among the noncompliant patients, three reported improvement and two reported no changes in their symptoms. Three patients reported further improvement between the second and third visit. In one patient the symptoms worsened, and in another they did not change.

\section{Initial findings in nerve conduction studies and in ultrasound}

The most frequent neurophysiological and sonographic findings were entrapment neuropathies of upper extremities: electrophysiologic diagnostics revealed CTS and UNE (unilateral or bilateral) in 6 out of 25 patients (24\%). Ultrasound showed CTS in 12 and UNE in 5 patients (48 and $20 \%$ respectively). The ulnar nerve was not examined with ultrasound in five patients, and the median nerve in one. Another patient allowed only limited neurophysiologic examination during the third visit, and therefore no motor conduction in the median nerves and no conduction in the sural nerve were studied. The detailed data on NCS and sonographic findings are summarized in the supplementary material.

\section{Electrophysiologic and sonographic changes under continuous positive airway pressure therapy}

After three months of CPAP there was neurophysiologic improvement in seven out of nine compression syndromes (CTS and UNE) among compliant patients (i.e. increase of sensory conduction velocity and shortening of distal motor latency in the median nerve for CTS, and increase in the motor conduction velocity across the elbow in the ulnar nerve for UNE). Two remaining compression syndromes showed no change (having either exactly the same value or - in the case of the median nerve - showing improvement in either sensory or motor conduction and a worsening in the other). The detailed
Table 2. Electrophysiologic changes of compression neuropathies of upper extremities under CPAP

\begin{tabular}{|c|c|c|c|c|}
\hline & & & $\begin{array}{l}3 \text { months } \\
\text { CPAP }\end{array}$ & $\begin{array}{l}9 \text { months } \\
\text { CPAP }\end{array}$ \\
\hline \multicolumn{5}{|c|}{ Compliant patients } \\
\hline \multicolumn{5}{|l|}{1} \\
\hline & Nondominant & CTS & - & - \\
\hline & Nondominant & UNE & & - \\
\hline \multicolumn{5}{|l|}{2} \\
\hline & Nondominant & CTS & $\uparrow$ & $\uparrow$ \\
\hline & Dominant & CTS & - & $\uparrow$ \\
\hline & Dominant & UNE & & - \\
\hline 3 & Dominant & CTS & $\uparrow$ & - \\
\hline 4 & Nondominant & UNE & & \\
\hline 5 & Nondominant & UNE & $\uparrow$ & \\
\hline 6 & \multicolumn{4}{|c|}{ No CTS/UNE in electrophysiology } \\
\hline 7 & \multicolumn{4}{|c|}{ No CTS/UNE in electrophysiology } \\
\hline 8 & Nondominant & UNE & & \\
\hline 9 & \multicolumn{4}{|c|}{ No CTS/UNE in electrophysiology } \\
\hline 10 & \multicolumn{4}{|c|}{ No CTS/UNE in electrophysiology } \\
\hline \multicolumn{5}{|c|}{ Noncompliant patients } \\
\hline \multicolumn{5}{|l|}{11} \\
\hline & Nondominant & CTS & - & \\
\hline & Dominant & CTS & - & - \\
\hline 12 & \multicolumn{4}{|c|}{ No CTS/UNE in electrophysiology } \\
\hline 13 & Nondominant & CTS & - & - \\
\hline 14 & \multicolumn{4}{|c|}{ No CTS/UNE in electrophysiology } \\
\hline \multicolumn{5}{|l|}{15} \\
\hline & Nondominant & CTS & $\uparrow$ & - \\
\hline & Nondominant & UNE & $\downarrow$ & - \\
\hline & Dominant & UNE & - & $\uparrow$ \\
\hline
\end{tabular}

Patient 5 did not come to the third visit ( 9 months under CPAP). In patient 11 nerve conduction study of the median nerve on the dominant side was not done during third visit.

CPAP - continuous positive airway pressure, CTS - carpal tunnel syndrome, UNE - ulnar neuropathy at the elbow, $\uparrow$ - electrophysiologic improvement of respective compression syndrome i.e. shortening of the distal motor latency (DML) and increase of the sensory conduction velocity across wrist (SNC) in the median nerve or increase of the motor conduction velocity $(\mathrm{MCN})$ across elbow in the ulnar nerve, $\downarrow$-electrophysiologic worsening of respective compression syndrome with opposite changes in comparison to improvement - no change i.e. exact the same values as in the previous measurement or - in case of the median nerve - improvement in sensory or motor conduction while worsening in the other.

Indications in the column "9 months under CPAP" are in respect to the measurements done three months under CPAP (column " 3 months under CPAP").

data regarding changes in respective nerve conduction are presented in Table 2.

The CSA of the median nerve at the wrist decreased in compliant patients after three months of CPAP, and again further decrease was observed after six months. The comparison between baseline measurements and measurements at the third visit showed significant reductions. The CSA of the ulnar nerve decreased after three months but then slightly increased. Considering that the CSA 
Jakub M. Antczak, Aleksander Kania, Maria Dąbroś, Kinga Budnicki, Ravin De Fonseka, Marta Banach, Agnieszka Słowik

Table 3. Changes in nerve conduction study and in ultrasound under continuous positive airway pressure

\begin{tabular}{|c|c|c|c|c|c|c|c|c|c|c|}
\hline & \multirow[t]{2}{*}{$n$} & \multicolumn{2}{|c|}{ Before CPAP } & \multicolumn{2}{|c|}{ After 3 months } & \multirow[t]{2}{*}{$p^{*}$} & \multicolumn{2}{|c|}{ After 9 months } & \multirow[t]{2}{*}{$p^{* *}$} & \multirow[t]{2}{*}{$p^{* * *}$} \\
\hline & & Mean & SD & Mean & SD & & Mean & SD & & \\
\hline \multicolumn{11}{|l|}{ Compliant patients } \\
\hline Sural SNAP amplitude & 10 & 10.6 & 6.3 & 10.6 & 5.1 & 1.000 & 7.8 & 4.4 & 0.123 & 0.076 \\
\hline Median DML & 4 in 3 patients & 4.5 & 0.6 & 4.2 & 1.0 & & 4.1 & 0.6 & & \\
\hline Median SCV & 4 in 3 patients & 41.6 & 4.3 & 45.8 & 4.4 & & 44.5 & 2.3 & & \\
\hline Ulnar MCV across elbow & 5 in 5 patients & 42.1 & 2.3 & 48.2 & 5.6 & & 47.1 & 7.0 & & \\
\hline Median CSA & 11 in 8 patients & 16.3 & 3.6 & 14.6 & 4.7 & 0.477 & 14.1 & 3.2 & 0.612 & 0.024 \\
\hline Ulnar CSA & 6 in 5 patients & 15.3 & 3.6 & 12.5 & 3.7 & & 12.6 & 3.8 & & \\
\hline Pooled M+U CSA & 17 in 8 patients & 15.9 & 3.5 & 13.9 & 4.4 & 0.005 & 13.6 & 3.3 & 0.610 & 0.005 \\
\hline \multicolumn{11}{|l|}{ Noncompliant patients } \\
\hline Sural SNAP amplitude & 5 & 15.6 & 5.7 & 9.8 & 3.8 & & 12.5 & 6.6 & & \\
\hline Median DML & 3 in 2 patients & 3.9 & 0.1 & 4.2 & 0.3 & & 4.3 & & & \\
\hline Median SCV & 1 & 46.7 & & 53.5 & & & 56.2 & & & \\
\hline Ulnar MCV across elbow & 1 & 46.2 & & 45.0 & & & 45.0 & & & \\
\hline Median CSA & 6 in 4 patients & 13.2 & 1.0 & 11.8 & 1.3 & & 11.8 & 1.5 & & \\
\hline Ulnar CSA & 1 & 15.0 & & 13.0 & & & 15.0 & & & \\
\hline Pooled M+U CSA & 7 in 5 patients & 13.4 & 1.1 & 12.0 & 1.3 & & 12.3 & 1.8 & & \\
\hline
\end{tabular}

CPAP - continuous positive airway pressure, after 3 months - after 3 months CPAP (second visit), after 9 months - after 9 months CPAP (third visit), SNAP - sensory nerve action potential, DML - distal motor latency, SCV - sensory conduction velocity, MCV - motor conduction velocity, CSA - cross-sectional area, Pooled M+U CSA - pooled CSA of the median and the ulnar nerves,

*Before CPAP vs. 3 months. **After 3 months vs. after 9 months. ${ }^{* * *}$ Before CPAP vs. after 9 months.

values of the median and ulnar nerve were similar, we pooled the data for both nerves. This comparison showed a significant reduction of the CSA after three months under CPAP, which persisted to the third visit. The respective data are presented in Table 3.

\section{DISCUSSION}

The data from our case series indicate that the main neuropathic changes in patients with OSAS are the common entrapment syndromes of the nerves of the upper extremities. These findings correlate, however, only partially with clinical symptoms, which tend to be more generalized, affecting all the extremities in the majority of the patients. The CPAP therapy may be beneficial for CTS and UNE by reducing nerve swelling and improving conduction.

Electrophysiologic diagnostics revealed CTS and UNE in $24 \%$ of our patients. Data from previous studies showed CTS in 27\% [4] and UNE in 42.9\% [5]. We included only patients with neuropathic symptoms, which might increase the prevalence. On the other hand, in a significant proportion of patients our testing omitted the dominant extremities, where entrapment neuropathies occur more frequently [12], which could significantly decrease the prevalence.

Surprisingly, the CTS was markedly more frequent in ultrasonography than in NCS (according to the best of the authors' knowledge our study was the first to use ultrasound to visualize the peripheral nerves in OSAS patients). Studies which compared both methods showed similar diagnostic accuracy [13], equal sensitivity [14], and close correlation in the assessment of severity of CTS [15]. In our sample the ultrasonography revealed twice as much CTS diagnoses as NCS. From this we derive the hypothesis that the CTS in patients with OSAS and in the general population may differ pathophysiologically. Peripheral edema, which is associated with OSAS [16], may also affect the peripheral nerves and in this way contribute additionally to the development of CTS and other entrapment neuropathies. The main mechanism underlying edema is probably hyperaldosteronism, found frequently in patients with OSAS [17]. Aldosterone enhances sodium and water retention and increases the amount of interstitial fluid, thus inducing the swelling of the nerve trunk. Another origin of edema and of the associated CTS and UNE may be nocturnal, intermittent hypoxemia, which induces nerve swelling mainly by altering the expression of the Aquaporin-1, the principal water channel of the peripheral nervous system [18].

Although the amplitude of the sural SNAP was decreased in only few of our patients, it showed an inverse correlation with AHI and ODI, thus replicating the previous finding that OSAS - apart from inducing neural edema - is a potential cause of axonal lesion of peripheral nerves [1]. 
Impact of obstructive sleep apnea syndrome on peripheral nerves and the effect of continuous positive airway pressure: a prospective observational case series

Wpływ obturacyjnego bezdechu sennego na nerwy obwodowe oraz efekt leczenia ciagłym dodatnim ciśnieniem w drogach oddechowych: prospektywna obserwacyjna seria przypadków

Our data indicate that CPAP therapy may decrease neural edema and improve conduction at entrapment sites. Normalization of nocturnal oxygenation and the previously documented reduction of the aldosterone level under CPAP [17] seem to be the most probable explanations for this result. This finding may have consequences for the management of entrapment neuropathies by expanding the indications for conservative rather than operative treatment when such neuropathy occurs in patients with OSAS. Our data did not replicate the results of Dziewas et al. [2], who reported an increased sural SNAP amplitude after CPAP. One reason may be the small sample size of our study. Another may be the longer duration of axonal damage, with its irreversibility.

Another surprising finding was the discrepancy between common complaint of numbness and other symptoms in the lower extremities and the relatively sparse, respective electrophysiologic findings. We speculate that symptoms like numbness may have in OSAS other origins than PNP. One of these may be the edema of lower extremities frequently associated with OSAS [19]. Another possibility may be the limitation of the effect of nocturnal hypoxemia on transient, nocturnal functional alteration instead of permanent structural change to the nerves. This hypothesis is supported by frequently reported aggravation of symptoms during the night in our patients.

The data from the noncompliant patients could be analyzed only descriptively due to the small sample size. The sonographic measurements also suggest some improvement within this group. Moreover, some of the noncompliant patients reported improvement in numbness and other subjective symptoms. This likely occurred because the some of noncompliant patients used therapy although for only limited time, and three out of the five patients used CPAP for about two hours per night on average.

\section{LIMITATIONS}

The size of the studied sample was small, which limited the number of comparative calculations and their power. It was, however, sufficient to detect the aspects in which the impact of OSAS on the peripheral nervous system was significant, and also where therapy with CPAP might produce benefits. Another limitation concerns the missing data, especially on the CSA of the ulnar nerve. While one can expect that the conclusions, which were drawn regarding the higher prevalence of CTS in ultrasound than in NCS, should be similar for UNE, the unsystematic collection of the data did not allow us to confirm this. Moreover, we examined nerves on the dominant side to a limited extent, i.e. only in the case of the presence of the respective symptoms. The reason for this was the lack of knowledge of such a high prevalence of compression neuropathies among OSAS patients (the study began before the those of Bilgin et al. $[4,5]$ were published). Focusing on nerve conduction studies on the nondominant side was similar to the approach of many previous studies, which investigated PNP using NCS and also ultrasound [20-22]. For future studies, we plan to focus on the systematic and bilateral examination of CTS and UNE in OSAS patients, employing a more specific interview, e.g. in the form of the Boston Carpal Tunnel Questionnaire [23].

\section{CONCLUSIONS}

The results indicate that CTS and UNE are the most frequent neuropathies in patients with OSAS. Both can be significantly more frequently documented with ultrasound than with electrophysiology. They may be also improved with CPAP therapy. Our data further indicate that the subjective symptoms typically associated with neuropathy, such as numbness, tend to be more generalized in OSAS patients than electrophysiologic and sonographic findings.

\section{Conflict of interest/Konflikt interesu}

Absent./Nie występuje.

Financial support/Finansowanie

This study has been supported by the intramural grant of the Jagiellonian University (N41/DBS/000198). 


\section{References/Piśmiennictwo}

1. Mayer P, Dematteis M, Pépin JL, Wuyam B, Veale D, Vila A, Lévy P. Peripheral neuropathy in sleep apnea. A tissue marker of the severity of nocturnal desaturation. Am J Respir Crit Care Med 1999; 159: 213-219.

2. Dziewas R, Schilling M, Engel P, Boentert M, Hor H, Okegwo A, et al. Treatment for obstructive sleep apnea: effect on peripheral nerve function. J Neurol Neurosurg Psychiatry 2007; 78: 295-297.

3. Mihalj M, Lušić L, Đogaš Z. Reduced evoked motor and sensory potential amplitudes in obstructive sleep apnea patients. J Sleep Res 2016; 25: 287-295.

4. Bilgin Topçuoğlu Ö, Oruç Ö, Saraç S, Çetintaş Afşar G, Uluç K. Carpal tunnel syndrome in obstructive sleep apnea patients. Noro Psikiyatr Ars 2017; 54: 307-311.

5. Bilgin Topçuoğlu Ö, Oruç Ö, Afşar GÇ, Saraç S, Uluç K. Ulnar nerve entrapment at elbow in obstructive sleep apnea patients: a randomized controlled trial. Sleep Breath 2017; 21: 45-51.

6. Feldman EL, Stevens MJ, Thomas PK, Brown MB, Canal N, Greene DA. A practical two-step quantitative clinical and electrophysiological assessment for the diagnosis and staging of diabetic neuropathy. Diabetes Care 1994; 17: 1281-1289.

7. Berry RB, Budhiraja R, Gottlieb DJ, Gozal D, Iber C, Kapur VK, et al.; American Academy of Sleep Medicine. Rules for scoring respiratory events in sleep: update of the 2007 AASM Manual for the Scoring of Sleep and Associated Events. Deliberations of the Sleep Apnea Definitions Task Force of the American Academy of Sleep Medicine. J Clin Sleep Med 2012; 8: 597-619.

8. Dyck PJ, Boes CJ, Mulder D, Millikan C, Windebank AJ, Dyck PJ, Espinosa R. History of standard scoring, notation, and summation of neuromuscular signs. A current survey and recommendation. J Peripher Nerv Syst 2005; 10: 158-173.

9. Martina IS, van Koningsveld R, Schmitz PI, van der Meché FG, van Doorn PA. Measuring vibration threshold with a graduated tuning fork in normal aging and in patients with polyneuropathy. European Inflammatory Neuropathy Cause and Treatment (INCAT) group. J Neurol Neurosurg Psychiatry 1998; 65: 743-747.

10. Oh SJ (ed.). Nerve Conduction Studies in Clinical Electromyography. New York: Lippincott William \& Wilkins; 2003.

11. Zaidman CM, Al-Lozi M, Pestronk A. Peripheral nerve size in normals and patients with polyneuropathy: an ultrasound study. Muscle Nerve 2009; 40: 960-966.

12. Reinstein L. Hand dominance in carpal tunnel syndrome. Arch Phys Med Rehabil 1981; 62: 202-203.

13. Visser LH, Smidt MH, Lee ML. High-resolution sonography versus EMG in the diagnosis of carpal tunnel syndrome. J Neurol Neurosurg Psychiatry 2008; 79: 63-67.

14. Fowler JR, Munsch M, Tosti R, Hagberg WC, Imbriglia JE. Comparison of ultrasound and electrodiagnostic testing for diagnosis of carpal tunnel syndrome: study using a validated clinical tool as the reference standard. J Bone Joint Surg Am 2014; 9: e148.

15. Bayrak IK, Bayrak AO, Tilki HE, Nural MS, Sunter T. Ultrasonography in carpal tunnel syndrome: comparison with electrophysiological stage and motor unit number estimate. Muscle Nerve 2007; 35: 344-348.

16. Whyte KF, Douglas NJ. Peripheral edema in the sleep apnea/hypopnea syndrome. Sleep 1991; 14: 354-356.

17. Barceló A, Piérola J, Esquinas C, de la Peña M, Arqué M, Alonso-Fernández A, et al. Relationship between aldosterone and the metabolic syndrome in patients with obstructive sleep apnea hypopnea syndrome: effect of continuous positive airway pressure treatment. PLoS One 2014; 9: e84362.

18. Zhang J, Xiong Y, Lu LX, Wang H, Zhang YF, Fang F, et al. AQP1 expression alterations affect morphology and water transport in Schwann cells and hypoxia-induced up-regulation of AQP1 occurs in a HIF-1a-dependent manner. Neuroscience 2013; 252: 68-79.

19. Shahmirzai R, Firouzifar M. Sleep apnea and idiopathic leg edema: a case control study. Acta Med Iran 2017; 55 : 612-615.

20. Kawai T, Takei I, Tokui M, Funae O, Miyamoto K, Tabata M, et al. Effects of epalrestat, an aldose reductase inhibitor, on diabetic peripheral neuropathy in patients with type 2 diabetes, in relation to suppression of $\mathrm{N}(\varepsilon)$-carboxymethyl lysine. J Diabetes Complications 2010; 24: 424-432.

21. Charles M, Soedamah-Muthu SS, Tesfaye S, Fuller JH, Arezzo JC, Chaturvedi N, Witte DR; EURODIAB Prospective Complications Study Investigators. Low peripheral nerve conduction velocities and amplitudes are strongly related to diabetic microvascular complications in type 1 diabetes: the EURODIAB Prospective Complications Study. Diabetes Care 2010; 33: 2648-2653.

22. Werner RA, Jacobson JA, Jamadar DA. Influence of body mass index on median nerve function, carpal canal pressure, and cross-sectional area of the median nerve. Muscle Nerve 2004; 30: 481-485.

23. Levine DW, Simmons BP, Koris MJ, Daltroy LH, Hohl GG, Fossel AH, Katz JN. A self-administered questionnaire for the assessment of severity of symptoms and functional status in carpal tunnel syndrome. J Bone Joint Surg Am 1993; 75: 1585-1592. 